\title{
TAS2R38 taste receptor gene and chronic rhinosinusitis: a bitter ending
}

\author{
Giulia Montrasio ${ }^{1 *}$, Stefania Gallo ${ }^{1}$, Sarah Grossi ${ }^{2}$, Giorgio Binelli², Raffaella Cinquetti ${ }^{2}$ Daniel Simmen ${ }^{3}$, \\ Paolo Castelnuovo ${ }^{1}$, Paola Campomenosi ${ }^{2}$ \\ From The 10th Symposium of Experimental Rhinology and Immunology of the Nose (SERIN 2015) \\ Stockholm, Sweden. 19-21 February 2015
}

\section{Background}

Chronic rhinosinusitis (CRS) is a frequent disease with a high social impact and multifactorial pathogenesis. Recently, single nucleotide polymorphisms (SNPs) within the TAS2R38 gene were pointed at as possible contributors to the complex gene-environment interactions in CRS. This hypothesis was supported by in vitro evidence of the protective effect exerted by the functional bitter taste receptor T2R38 on sinonasal mucosa, due to its role in innate immunity. The purpose of this study was to confirm the proposed correlation between TAS2R38 genotype and CRS comorbidities and to assess whether the presence of a particular allele can be considered a prognostic marker.

\section{Methods}

Fifty-three CRS patients and thirty-nine healthy individuals were genotyped at the TAS2R38 locus. CRS patients were treated by endoscopic sinus surgery and medical therapies and subdivided in "recalcitrant" and "healed", depending on the clinical outcome, assessed by internationally accepted scoring systems. Chi-square analyses were used to assess the effect of genotype on CRS and CRS-related comorbidities.

\section{Results}

The distribution of the different genotypes at the TAS2R38 locus was not significantly different between recalcitrant CRS patients, healed CRS patients and controls $\left(\chi_{[10]}^{2}=2.75, \mathrm{p}=0,99\right)$. Besides, no associations were found between the different genotypes at the TAS2R38 locus and CRS-related comorbidities.

\section{Conclusions}

No association was found between TAS2R38 alleles or genotypes and CRS, thus questioning its real contribution to CRS susceptibility. Further studies on larger cohorts are needed to verify these findings also in vivo and to shed light on the role of bitter taste receptors in CRS.

\section{Authors' details \\ ${ }^{1}$ University of Insubria, ENT Department, Varese, Italy. ${ }^{2}$ University of Insubria, Dipartimento di Biotecnologie e Scienze della Vita, Varese, Italy. ${ }^{3}$ Klinik} Hirslanden, ORL-Zentrum, Zurich, Switzerland.

Published: 26 June 2015

doi:10.1186/2045-7022-5-S4-P3

Cite this article as: Montrasio et al.: TAS2R38 taste receptor gene and chronic rhinosinusitis: a bitter ending. Clinical and Translational Allergy 2015 5(Suppl 4):P3.

${ }^{1}$ University of Insubria, ENT Department, Varese, Italy

Full list of author information is available at the end of the article

Submit your next manuscript to BioMed Central and take full advantage of:

- Convenient online submission

- Thorough peer review

- No space constraints or color figure charges

- Immediate publication on acceptance

- Inclusion in PubMed, CAS, Scopus and Google Scholar

- Research which is freely available for redistribution

Submit your manuscript at www.biomedcentral.com/submit
() Biomed Central
C Biomed Central

(c) 2015 Montrasio et al. This is an Open Access article distributed under the terms of the Creative Commons Attribution License (http://creativecommons.org/licenses/by/4.0), which permits unrestricted use, distribution, and reproduction in any medium, provided the original work is properly cited. The Creative Commons Public Domain Dedication waiver (http://creativecommons.org/ publicdomain/zero/1.0/) applies to the data made available in this article, unless otherwise stated. 